\title{
Factors influencing heterogeneity of radiation- induced DNA-damage measured by the alkaline comet assay
}

\author{
Clemens Seidel ${ }^{1}$, Christine Lautenschläger ${ }^{2}$, Jürgen Dunst ${ }^{3}$ and Arndt-Christian Müller ${ }^{4^{*}}$
}

\begin{abstract}
Background: To investigate whether different conditions of DNA structure and radiation treatment could modify heterogeneity of response. Additionally to study variance as a potential parameter of heterogeneity for radiosensitivity testing.

Methods: Two-hundred leukocytes per sample of healthy donors were split into four groups. I: Intact chromatin structure; II: Nucleoids of histone-depleted DNA; III: Nucleoids of histone-depleted DNA with 90 mM DMSO as antioxidant. Response to single (I-III) and twice (IV) irradiation with 4 Gy and repair kinetics were evaluated using \% Tail-DNA. Heterogeneity of DNA damage was determined by calculation of variance of DNA-damage $(V)$ and mean variance (Mvar), mutual comparisons were done by one-way analysis of variance (ANOVA).

Results: Heterogeneity of initial DNA-damage (I, 0 min repair) increased without histones (II). Absence of histones was balanced by addition of antioxidants (III). Repair reduced heterogeneity of all samples (with and without irradiation). However double irradiation plus repair led to a higher level of heterogeneity distinguishable from single irradiation and repair in intact cells. Increase of mean DNA damage was associated with a similarly elevated variance of DNA damage $(r=+0.88)$.

Conclusions: Heterogeneity of DNA-damage can be modified by histone level, antioxidant concentration, repair and radiation dose and was positively correlated with DNA damage. Experimental conditions might be optimized by reducing scatter of comet assay data by repair and antioxidants, potentially allowing better discrimination of small differences. Amount of heterogeneity measured by variance might be an additional useful parameter to characterize radiosensitivity.
\end{abstract}

Keywords: Heterogeneity, Comet assay, \%Tail DNA, Antioxidants, Histones

\section{Introduction}

Reliable determination of radiosensitivity is of great importance in radiation oncology [1]. However, intraindividual heterogeneity and inter-individual variability of radiation-induced DNA damage limit test sensitivity, particularly in cases of small differences in radiosensitivity. Variability can be reduced by a highly standardized operation protocol and human reference sample [2]. Regarding heterogeneity, there are some assumptions relating this phenomenon to functionally radio-resistant

\footnotetext{
* Correspondence: arndt-christian.mueller@med.uni-tuebingen.de

${ }^{4}$ Department of Radiooncology, Eberhard-Karls-University,

Hoppe-Seyler-Strasse 3, Tübingen, Germany

Full list of author information is available at the end of the article
}

subpopulations [3,4]. Despite recent advances, a clear differentiation of radio-resistant subgroups within a cell line by cell surface markers or other criteria is not possible [5].

To study reasons for and the extent of heterogeneity, we searched for a cell model with an almost homogeneous response to irradiation to attribute changes of distribution to heterogeneity-inducing factors more easily. Radio-sensitive cells without extreme differences in response to irradiation appeared appropriate for this. We therefore used leukocytes from healthy volunteers to investigate how little intrinsic heterogeneity [6,7] might be influenced by changes in DNA conformation, antioxidant level and different radiation schedules. Radiation-

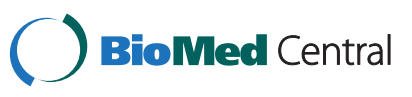

(c) 2012 Seidel et al.; licensee BioMed Central Ltd. This is an Open Access article distributed under the terms of the Creative Commons Attribution License (http://creativecommons.org/licenses/by/2.0), which permits unrestricted use, distribution, and reproduction in any medium, provided the original work is properly cited. 
induced DNA damage was measured by single cell gel electrophoresis (SCGE, also called comet assay) initially established by Östling and Johannson [8] capable in its alkaline modification of detecting single strand breaks (SSB), alkali labile sites and incomplete excision repair sites [9-11]. We defined heterogeneity as variance of DNA damage since this parameter was usually applied to describe the scattering of data.

The aim of the present study was to evaluate whether heterogeneity could be modified by treatment related (radiotherapy and repair) or structural conditions (radical scavenging property, DNA organisation). Furthermore, the present study investigated whether variance as descriptor of heterogeneity could become a useful parameter to give additional aspects of radiation sensitivity.

\section{Material and methods}

Chemicals were purchased from the following suppliers: Agarose, low melting point (LMP) agarose and phosphatebuffered saline (PBS) from Gibco BRL, Paisley, UK; RPMI 1640 (with $25 \mathrm{mM}$ Hepes and L-Glutamine) from Biowhittaker Europe, Verviers, Belgium; fetal calf serum from Biochrom AG, Berlin, Germany; Sodium chloride from Roth, Karlsruhe, Germany; EDTA, Triton X100 and propidium iodide from Sigma, Deisenhofen, Germany; Tris(hydroxymethylaminomethane), DMSO, sodium hydroxide and hydrochloric acid from Merck, Darmstadt, Germany.

Blood samples were collected in citrate and EDTA tubes from five healthy volunteers (informed consent was obtained) with the following characteristics: Young age (20-25 years), no exhaustive physical activity, no smoking history, no acute or chronic disease, no vegetarian eating habits, no vitamin supplements and no medication except for contraceptives. Blood cell counts (EDTA-tubes) were taken to ensure leukocyte levels were in the reference range. Each citrate blood sample was split into several fractions for separate treatment to evaluate different conditions of DNA-organisation.

The alkaline technique described by Singh et al. [11,12] was used with some modifications [13]. In brief, experiments were performed in sandwichlayer-technique on fully frosted slides which were pre-coated with a temporary agarose layer (1000 $\mu \mathrm{l}, 1 \%$ in PBS). Single cells (25.00040.000 cells per slide) were embedded in LMP-agarose (85 $\mu \mathrm{l}, 0.5 \%)$ with RPMI 1640 above a layer consisting of agarose $(300 \mu \mathrm{l}, 0.6 \%$ in PBS). Subsequently the slides were covered by a top layer of LMP-agarose with RPMI 1640 .

In a first set of experiments (200 leukocytes/sample of one donor), increasing radiation doses of 0-8 Gy were used to test the sensitivity of comet assay for subpopulations to define optimal radiation dose. Thereafter, three different conditions of DNA-organisation or antioxidant level were investigated in leukocytes, later referred to as fraction I-III (Figure 1). Fraction I contained unchanged cells with complete chromatin structure and antioxidants, i.e. control cells. Fraction II was lysed at $4^{\circ} \mathrm{C}$ for $60 \mathrm{~min}$ in a solution of $1.5 \mathrm{M}$ sodium chloride and 1\% Triton-X 100 to develop histone-depleted DNA anchored to nuclear matrix [14]. Fraction III consisted of almost pure DNA of fraction II supplemented by antioxidants (90 mM DMSO), approximately equal to intracellular scavenging capacity [15]. Irradiation of slides (fraction I-III) was performed between piacryl plates using a Philips RT $250(200 \mathrm{kV}$, dose rate of $208.3 \mathrm{cGy} / \mathrm{min}$ ). To evaluate whether double fractionated

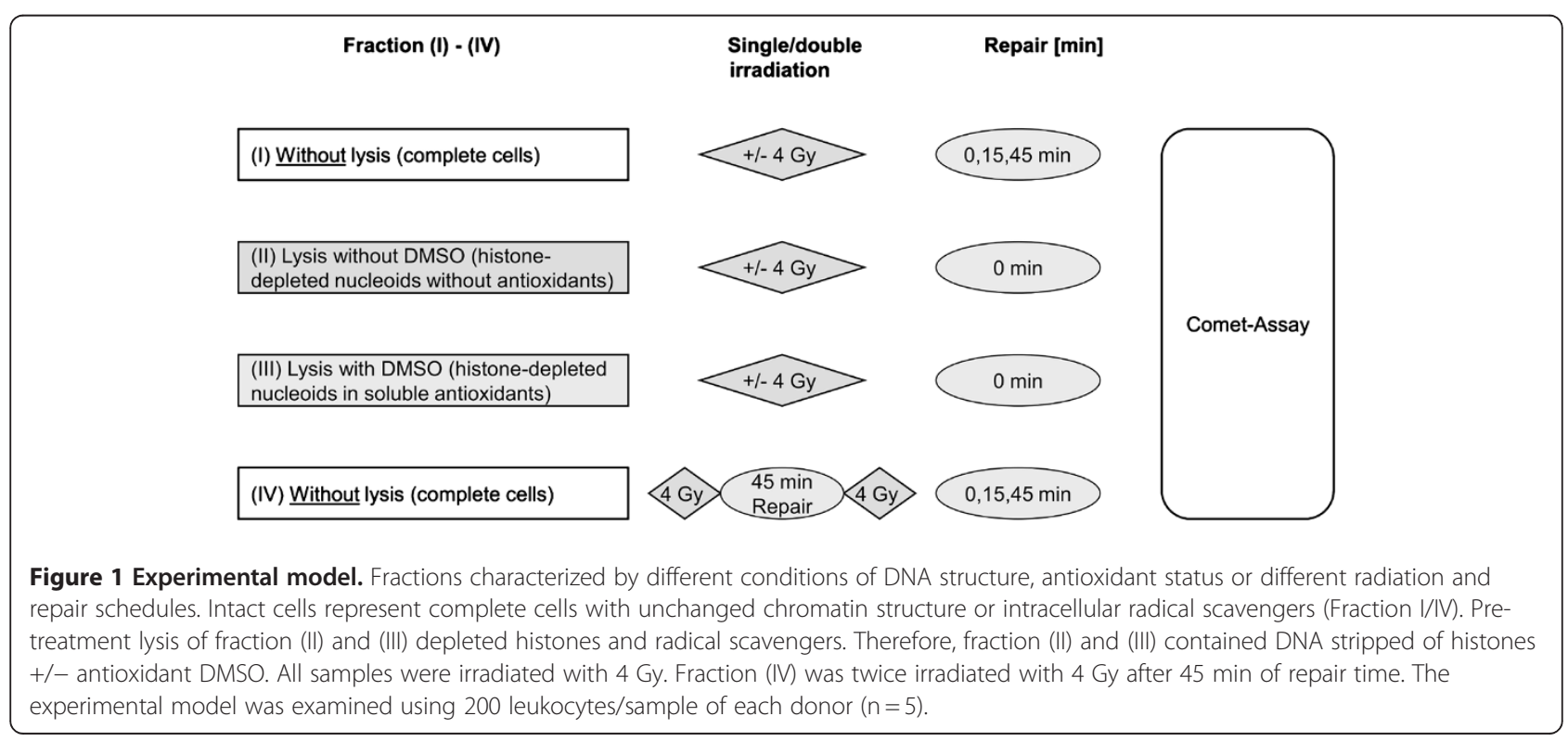


irradiation could be usable as discriminator of individual heterogeneity, we irradiated untreated cells (fraction IV) after a repair period of $45 \mathrm{~min}$ again, Figure 1 . The time interval between both radiation treatments was based on previous repair investigations showing that $45 \mathrm{~min}$ were sufficient to reach basal level of DNA damage. For DNA repair studies, the cells of fraction I and IV were incubated for 0,15 or 45 min in complete medium (85\% RPMI 1640, $15 \%$ fetal calf serum) at $37^{\circ} \mathrm{C}$.

The slides were transferred to alkaline lysis solution (2.5 M sodium chloride, $90 \mathrm{mM}$ EDTA, $10 \mathrm{mM}$ Tris, $190 \mathrm{mM}$ sodium hydroxide, $1 \%$ Triton-X 100 and $90 \mathrm{mM}$ DMSO, $\left.\mathrm{pH}=10 ; \mathrm{T}=4^{\circ} \mathrm{C}\right)$ for $3 \mathrm{~h}$. Alkaline unwinding $(1 \mathrm{~h})$ and horizontal gel electrophoresis $(0.8 \mathrm{~V} / \mathrm{cm}, 25 \mathrm{~V}$, $300 \mathrm{~mA}, 30 \mathrm{~min}$ ) were subsequently performed in the same electrophoretic buffer (2 mM EDTA, 0.6 M NaOH; $\mathrm{pH} \geq 13.3 ; \mathrm{T}=12-14^{\circ} \mathrm{C}$ ). After $12 \mathrm{~h}$ of neutralisation in $0.4 \mathrm{M}$ Tris $-\mathrm{HCl}\left(\mathrm{pH}=7.5 ; \mathrm{T}=4^{\circ} \mathrm{C}\right)$ all slides were stained with $100 \mu \mathrm{l}$ of $1 \%$ propidium iodide. DNA damage was determined by a Zeiss fluorescence microscope with a CCD video camera (Pulnix-765E, Kinetic Imaging) and an image processing system (Comet $3.1^{\circledR}$-Kinetic Imaging). At least duplicate slides were evaluated for each donor $(n=5)$. Two-hundred cells per fraction for each donor were analyzed using \%Tail-DNA to describe DNA-damage. Basal damage was defined as damage without irradiation. Initial damage was directly assessed after irradiation $(0 \mathrm{~min}$ repair time). Residual damage represented the remaining damage after repair time.

Heterogeneity of DNA damage was evaluated by variance (V) of DNA damage in \%Tail-DNA, for each fraction (5 samples, i.e. 1.000 comet measurements) mean variance $\left(\mathrm{M}_{\mathrm{var}}\right)$ was determined. Mutual comparisons between fractions were performed by one-way analysis of variance (ANOVA) accepting a p-value below 0.05 for significance. Statistical analysis, diagram, histogram plots, regression analysis and Pearson's correlation were performed with SPSS 10.0 (Software, SPSS Inc.) and Microsoft Office (Software, Microsoft Corp.).

\section{Results}

\section{Methodological considerations}

Before testing of different DNA-conditions, distribution of DNA damage at increasing radiation doses was investigated to define the optimal radiation dose for evaluation of heterogeneity. DNA-damage distribution of one donor was therefore evaluated in a histogram plot, Figure $2 \mathrm{a}$. Leukocytes show a left-sided asymmetric curve of DNA basal damage (0 Gy control sample) and reach a nearly bell-shaped curve after 4 Gy. To test the sensitivity of the comet assay for subpopulations, samples irradiated with different doses $(0,2,4$ or $8 \mathrm{~Gy})$ were mixed in equal proportions (1:1). Thirty $\mu \mathrm{l}$ of one sample was combined with the next higher irradiation dose level sample. Comparison of means demonstrated highly significant differences in almost all pairs and a trend for cells irradiated with 2 Gy versus $2+4$ Gy (Table 1). At least two populations were detectable for mixture-samples from 0 to 4 Gy, as indicated by an arrow between both peaks in Figure 2a. A clear detection of different populations in mixture $4+8$ Gy was impossible due to superimposing caused by a low ascent of both singular curves for 4 and 8 Gy. Regarding histograms, mean differences and standard deviations, we decided to use 4 Gy as optimal radiation dose, enabling best differentiation of DNA damage from baseline and allowing detection of subpopulations (Figure 2a/b).

\section{Heterogeneity measured by variance}

The experimental schedule was performed as demonstrated in Figure 1 for different DNA-organisations (fraction I-III) or radiation schedules (fraction IV). DNA damage of two-hundred single cells was measured in \%Tail DNA and heterogeneity of damage was estimated by variance. Mean DNA damage in \%Tail DNA, mean variance $\left(\mathrm{M}_{\mathrm{Var}}\right)$ and one-way analysis of variance (ANOVA) were calculated as shown in Table 2, 3 and Figure 3a.

Comparison of heterogeneity of fraction I-III demonstrated highest variance for fraction II with and without irradiation. However, there was no difference between variance of fraction I and III (line 1-6 of Table 2). Intrafractional comparison of 0 vs. 4 Gy (Table 2, line 7-9) revealed that heterogeneity increased with radiation dose of 4 Gy in all fractions by two- to fivefold reaching significance (fraction II, III) or a trend with $\mathrm{p}=0.07$ (fraction I). Otherwise, heterogeneity and related DNA-damage decreased significantly with repair time after single irradiation (fraction I, Table 2, line 10-12). The same result was found after double fractionated irradiation with increasing repair time (Table 2, line 13-15), but a significant reduction of heterogeneity required more than 15 min of repair time. When single and double fractionated irradiation (fraction I vs. IV) after same repair periods were compared (Table 2, line 16-18), heterogeneity of double fractionated irradiated samples always remained significantly higher than samples after single irradiation. However, absolute levels of DNA damage were in the same range (29.3 vs. 26.5 \%Tail DNA at $2 \times 4$ vs. 4 Gy, Table 3). Therefore, a second radiation course was clearly distinguishable from single irradiation by variance while absolute DNA damage was equal.

\section{Heterogeneity, a multi-component model}

The relative and absolute influence of the parameters described above on heterogeneity was illustrated for irradiation with 4 Gy in Figure 3b. Nucleoids of DNA with depleted histones (fraction II) showed a maximum of DNA damage and heterogeneity. Heterogeneity was reduced to about one third in intact cells and addition of repair time led to further significant reduction of heterogeneity. 


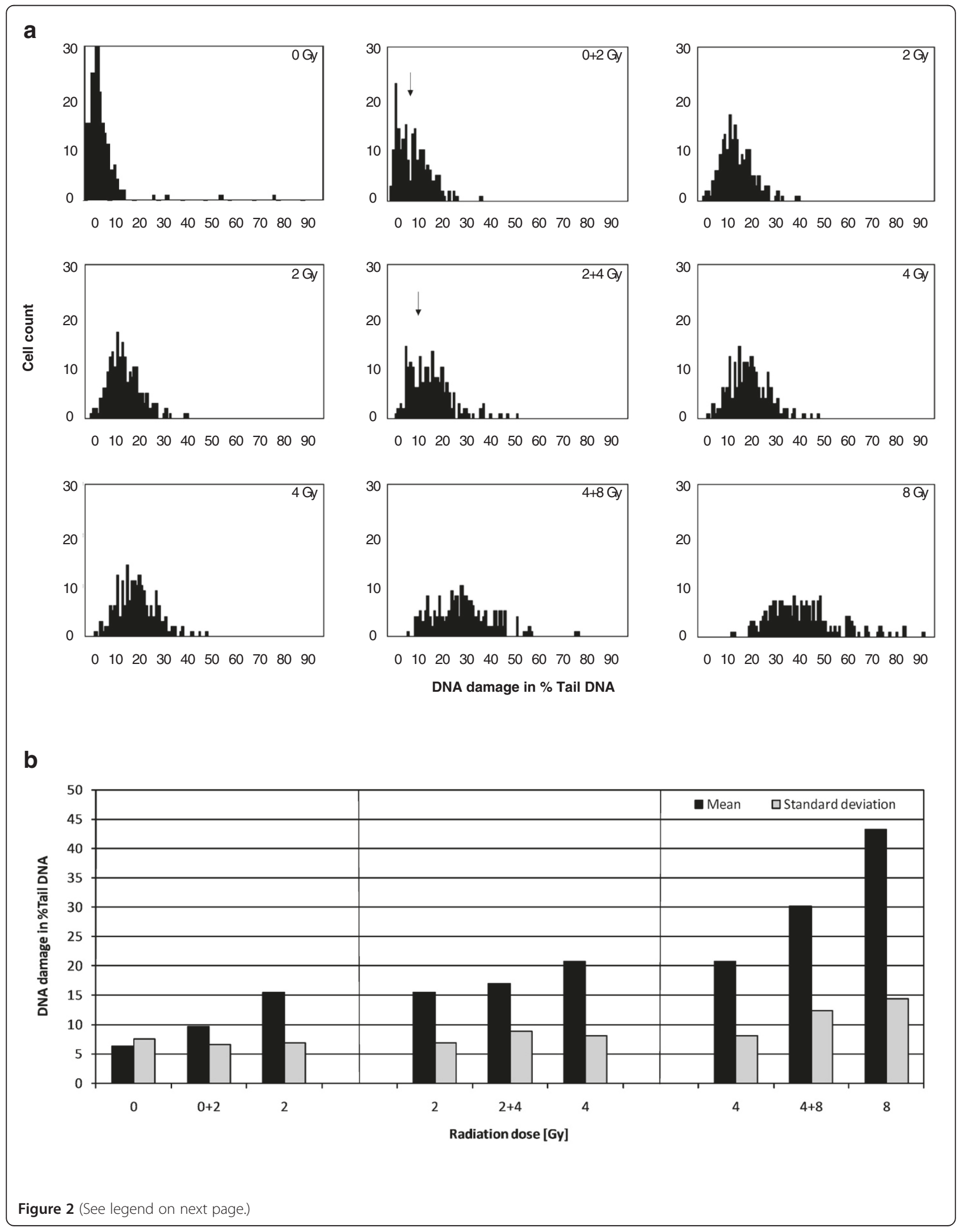


(See figure on previous page.)

Figure 2 Discrimination of heterogeneity with the alkaline Comet assay. The sensitivity of the comet assay for subpopulations was investigated. Therefore, samples treated with 0, 2, 4 or 8 Gy and cell mixtures ( 0 and 2 Gy, 2 and 4 Gy, 4 and 8 Gy) were analysed (200 leukocytes/sample of one donor). The respective histograms (a) and DNA damage in \%Tail DNA with the corresponding standard deviations (b) were demonstrated. Two populations were detectable for mixture-samples from 0 to 4 Gy as indicated by a subdividing arrow.

\section{Correlation between \% tail DNA and variance}

We graphically evaluated the direction of mean DNA damage in \%Tail DNA and mean variance depending on the conditions described above. Increasing DNA damage in \%Tail DNA also increased the mean variance in almost all samples. Pearson and Bravais' correlation of DNA damage and variance substantiated this finding by a significant positive correlation (Correlation coefficient $\mathrm{r}=+0.880 ; \mathrm{p}<0.001$, Figure 3c). Multiple linear regression calculated an $\mathrm{R}^{2}$ of 0.771 indicating a $77.1 \%$ dependency of variance on changes of DNA damage. The linear regression coefficient of mean DNA damage was 4.273 (two-tailed significance level $\mathrm{p}<0.001$ ) substantiating that \%Tail DNA and variance of DNA damage correlated positively.

\section{Discussion}

We demonstrated a simple method to compare heterogeneity by variance analysis. This study is the first - to our knowledge - to confirm that heterogeneity of DNA damage can be selectively modified and is not a constant biological phenomenon. Our results visualize the wide range of heterogeneity substantiated by considerable inor decreases of variance induced by biological factors as shown in Table 4 and Figure 3. Olive et al. also attributed most proportion of heterogeneity to biological (and not technical) reasons and explained heterogeneity by different susceptibility of areas to loose supercoiling after

Table 1 Discrimination of heterogeneity with the alkaline comet assay

\begin{tabular}{rrrrrr}
\hline & & \multicolumn{4}{c}{ Paired comparison } \\
\cline { 5 - 6 } Sample & \%Tail DNA & SD & Compared pair & F-value & p-value \\
\hline 0 Gy & 6.2 & 7.6 & & & \\
$0+2$ Gy & 9.7 & 6.5 & 0 Gy / 0 + 2 Gy & 24.03 & $<0.001$ \\
2 Gy & 15.5 & 6.9 & $0+2$ Gy / 2 Gy & 74.31 & $<0.001$ \\
$2+4$ Gy & 16.9 & 8.9 & 2 Gy / 2 + 4 Gy & 3.220 & 0.073 \\
4 Gy & 20.7 & 8.1 & $2+4$ Gy / 4 Gy & 20.36 & $<0.001$ \\
$4+8$ Gy & 30.1 & 12.3 & 4 Gy / 4 + 8 Gy & 80.78 & $<0.001$ \\
8 Gy & 43.1 & 14.4 & $4+8$ Gy / 8 Gy & 94.78 & $<0.001$ \\
\hline
\end{tabular}

Leukocytes (200 leukocytes/sample of one donor) were irradiated with increasing doses (0-8 Gy) and mixed in equal proportions with the next higher irradiation dose level sample. Comparison of mean DNA damage in \%Tail DNA for samples treated with $0,2,4$ or 8 Gy and mixtures ( 0 and 2 Gy, 2 and $4 \mathrm{~Gy}$, 4 and $8 \mathrm{~Gy}$ ) revealed significant differences for almost all pairs and a trend for cells irradiated with 2 Gy vs. $2+4 \mathrm{~Gy}$.

Abbreviations: $\mathrm{SD}=$ standard deviation, $\mathrm{p}$-value = probability value, F-value. receiving DNA damage [16]. Practical implications for radiosensitivity testing in certain situations can be derived: In general, best discrimination of cell lines is possible when there is a large difference in absolute DNA damage and heterogeneity of response is low. If the first condition cannot be met, we recommend evaluating single or double fractionated irradiation and repair phase by ANOVA, because heterogeneity measured as variance generated better distinguishable i.e. significant differences during repair phase ( 0 vs. $45 \mathrm{~min}$ ) in contrast to lower changes in absolute DNA damage as shown in Table 2 and 3. Therefore,

\section{Table 2 ANOVA of mean variance}

\begin{tabular}{|c|c|c|c|c|c|}
\hline \multicolumn{6}{|c|}{ ANOVA of mean variances } \\
\hline Sample & $M_{\text {Var }}$ & Sample & $\mathrm{M}_{\mathrm{Var}}$ & F-value & p-value \\
\hline OGy (I) & 47.63 & OGy (II) & 83.81 & 2.493 & 0.153 \\
\hline OGy (I) & 47.63 & OGy (III) & 23.03 & 2.551 & 0.149 \\
\hline OGy (II) & 83.81 & OGy (III) & 23.03 & 11.624 & 0.009 \\
\hline 4Gy (I) & 86.53 & 4Gy (II) & 284.02 & 23.365 & 0.001 \\
\hline 4Gy (I) & 86.53 & 4Gy (III) & 106.01 & 1.807 & 0.216 \\
\hline 4Gy (II) & 284.02 & 4Gy (III) & 106.01 & 9.506 & 0.002 \\
\hline OGy (I) & 47.63 & 4Gy (I) & 86.53 & 4.328 & 0.071 \\
\hline OGy (II) & 83.81 & 4Gy (II) & 284.02 & 21.728 & 0.002 \\
\hline OGy (III) & 23.03 & 4Gy (III) & 106.01 & 70.647 & $<0.001$ \\
\hline 4Gy (I) & 86.53 & $4 \mathrm{~Gy}+15 \min (\mathrm{I})$ & 48.96 & 10.140 & 0.013 \\
\hline 4Gy (I) & 86.53 & $4 G y+45 \min (I)$ & 31.92 & 20.575 & 0.002 \\
\hline $4 \mathrm{~Gy}+15 \min (\mathrm{I})$ & 48.96 & $4 G y+45 \min (I)$ & 31.92 & 9.887 & 0.014 \\
\hline $2 \times 4 G y(I V)$ & 120.51 & $2 \times 4 G y+15 \min (I V)$ & 138.36 & 0.947 & 0.359 \\
\hline 2x4Gy (IV) & 120.51 & $2 \times 4 G y+45 \min (I V)$ & 67.67 & 31.585 & $<0.001$ \\
\hline $2 \times 4 G y+15 \min (I V)$ & 138.36 & $2 \times 4 G y+45 \min (\mathrm{IV})$ & 67.67 & 14.608 & 0.005 \\
\hline 2x4Gy (IV) & 120.51 & 4Gy (I) & 86.53 & 6.839 & 0.031 \\
\hline $2 \times 4 G y+15 \min (I V)$ & 138.36 & $4 G y+15 \min (I)$ & 48.96 & 26.039 & 0.001 \\
\hline $2 \times 4 G y+45 \min (I V)$ & 67.67 & $4 G y+45 \min (I)$ & 31.92 & 19.795 & 0.002 \\
\hline
\end{tabular}

Analysis of variance (ANOVA) was performed for the following pairs (1.-6.) of fraction I-IV ${ }^{*}$. (1.) Influence of DNA structure, antioxidants on heterogeneity of DNA damage without irradiation (line 1-3) and (2.) with irradiation (line 4-6). (3.) Influence of different radiation doses (line 7-9), (4.) heterogeneity of samples with increasing repair periods after single (line 10-12) and double fractionated irradiation (line 13-15) and (6.) comparison of single vs. double fractionated irradiation after same repair periods (line 16-18). In brief, heterogeneity was always significantly increased in histone- and antioxidantdepleted cells (fraction II) and after single or double fractionated irradiation but decreased with repair time or addition of antioxidants. Related mean variance (five donors) and mean DNA damage were shown in Figure $3 a$ Abbreviations: $\mathrm{F}=\mathrm{F}$-value, $\mathrm{p}=$ probability value. $\mathrm{M}_{\mathrm{Var}}=$ mean variance.

* 200 leukocytes/sample of each donor were measured for calculation of DNA damage in \%Tail DNA and variance. Mean variance was calculated from 5 donors. 
Table 3 Absolute DNA damage in \%Tail DNA of fraction I-IV

\begin{tabular}{|c|c|c|c|c|c|c|c|c|c|}
\hline \multirow[t]{2}{*}{$\mathrm{n}$} & \multirow[t]{2}{*}{ Fraction } & \multirow[t]{2}{*}{ [Gy] } & \multirow[t]{2}{*}{ Repair [min] } & \multicolumn{5}{|c|}{ \%Tail DNA of five donors } & \multirow{2}{*}{$\frac{\text { Mean } \%}{\text { Tail DNA }}$} \\
\hline & & & & Donor1 & Donor2 & Donor3 & Donor4 & $\overline{\text { Donor5 }}$ & \\
\hline 1 & I & 0 & 0 & 5.91 & 5.56 & 4.60 & 7.45 & 5.89 & 5.88 \\
\hline 2 & $\|$ & 0 & 0 & 20.19 & 24.39 & 16.66 & 12.38 & 17.31 & 18.19 \\
\hline 3 & III & 0 & 0 & 6.56 & 6.68 & 6.19 & 6.82 & 7.83 & 6.82 \\
\hline 4 & $\|$ & 4 & 0 & 64.44 & 62.09 & 57.45 & 61.83 & 60.54 & 61.27 \\
\hline 5 & III & 4 & 0 & 23.02 & 31.20 & 34.51 & 37.96 & 34.83 & 32.30 \\
\hline 6 & I & 4 & 0 & 24.90 & 28.56 & 25.95 & 25.91 & 27.17 & 26.50 \\
\hline 7 & I & 4 & 15 & 11.45 & 12.22 & 12.83 & 11.11 & 10.99 & 11.72 \\
\hline 8 & I & 4 & 45 & 7.75 & 7.89 & 6.61 & 6.13 & 8.89 & 7.45 \\
\hline 9 & IV & $2 \times 4$ & 0 & 30.05 & 29.58 & 31.94 & 25.88 & 29.27 & 29.34 \\
\hline 10 & IV & $2 \times 4$ & 15 & 19.11 & 19.16 & 21.39 & 19.92 & 20.95 & 20.11 \\
\hline 11 & IV & $2 \times 4$ & 45 & 12.02 & 11.45 & 9.79 & 15.54 & 12.90 & 12.34 \\
\hline
\end{tabular}

Mean DNA damage in \%Tail DNA of donor leukocytes for fraction I-IV was represented*. The highest levels of basal and initial DNA damages (at 0 and 4 Gy) were detected for nucleoids without antioxidants or histones (fraction II).

* 200 leukocytes/sample of each donor were measured for calculation of DNA damage in \%Tail DNA and variance. Mean variance was calculated from 5 donors.

variance analysis after single/double fractionated irradiation and of repair phase might broaden the spectrum of radiosensitivity assessment and help to discriminate cell lines with the same absolute response rates but different heterogeneity.

A precondition of our study was a method capable of determining heterogeneity including subpopulations. Comet assay fulfilled this condition, as shown by experiments with differentially irradiated cell mixtures and confirmed by other investigators [17-20]. Furthermore, excellent reproducibility and sensitivity for detection of small drug- or radiation-related damages were substantiated for SCGE [21-25] and led to its application in biomonitoring studies [13,26,27]. Therefore, this method was chosen to investigate the hypothesis that heterogeneity might be related to DNA-conformation, radical scavenging capacity and treatment.

A potential limitation of this study might be the use of leucocytes i.e. of lymphocytes and granulocytes/monocytes. Regarding initial damages without repair, no relevant differences in radiosensitivity were observed for different blood cells [28]. Otherwise, Banath et al. re-ported about slightly faster repair of blood cells compared to isolated lymphocytes which was partly related to different experimental conditions (additional separation procedure for lymphocytes and irradiation in blood tubes compared to frosted slides in this study) [29]. However, all donors in this study had to fulfil inclusion criteria ensuring that the blood cell count was in the reference range excluding larger differences between blood subpopulations of the donors. Furthermore, we performed intraindividual experiments i.e. one blood sample of the donor was divided in the different fractions (I-IV) as described in Figure 1.
Therefore, all samples/fractions of one donor contained the same distribution of blood cells minimising potential bias.

We used a model of nucleoids (i.e. DNA with depleted histones) without antioxidants (fraction II) [14] and a second nucleoid model with antioxidants (fraction III) [15]. Different amounts of chromatin or antioxidants are associated with quantitative and qualitative differences in DNA damage $[14,15]$ and with changes of heterogeneity in this setting. Independent of multiple processes, underlying repair and chromatin interactions such as chromatin remodelling [30], chromatin structure at time of damage [31-33] and many others, we detected a significant reduction of heterogeneity with repair time. This effect partly contributes to a repair-related reduction of absolute DNA damage and due to positive correlation with heterogeneity, variance is also reduced. Furthermore, the rearrangement of chromatin remodelling-complexes itself facilitates nucleotide excision repair [34], explaining an amplification of DNA damage reduction. In addition, the susceptibility to radiation-induced hydroxyl radicals changes due to different radical scavenging property of complexed histones [35].

However, the presence of a high concentration of radical scavengers (fraction III) switched heterogeneity to the same level as complete cells, leading to the conclusion that an increase in antioxidants reduces heterogeneity as well as absolute DNA damage. This was also reported by Tiwari et al. [36]. To better visualize this multi-component model of heterogeneity, we marked modifications of absolute damage in \%Tail DNA and heterogeneity with arrows, Table 4. The positive correlation of heterogeneity and DNA response is obvious. However, the only parameter which clearly increased heterogeneity while \%Tail DNA persisted was 


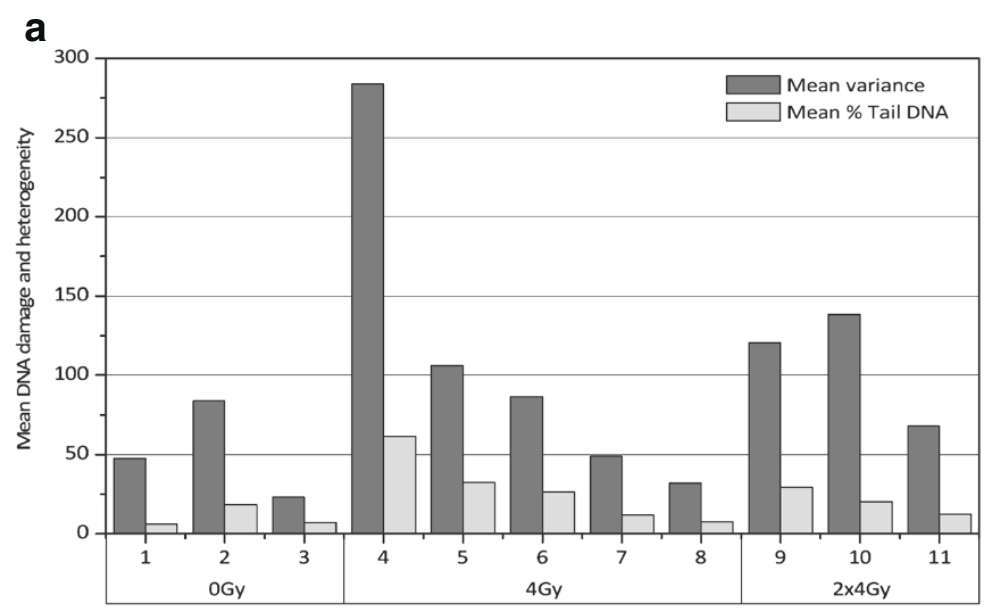

$\begin{array}{llll}\text { n } & \text { Fraction } & \text { Gy } & \text { Repair } \\ 1 & \text { Fraction (I) } & 0 G y & 0 \text { min } \\ 2 & \text { Fraction (II) } & 0 G y & 0 \text { min } \\ 3 & \text { Fraction (III) } & 0 G y & 0 \text { min } \\ 4 & \text { Fraction (II) } & 4 G y & 0 \text { min } \\ 5 & \text { Fraction (III) } & 4 G y & 0 \text { min } \\ 6 & \text { Fraction (I) } & 4 G y & 0 \text { min } \\ 7 & \text { Fraction (I) } & 4 G y & 15 \mathrm{~min} \\ 8 & \text { Fraction (I) } & 4 G y & 45 \mathrm{~min} \\ 9 & \text { Fraction (IV) } & 2 \times 4 G y & 0 \mathrm{~min} \\ 10 & \text { Fraction (IV) } & 2 \times 4 G y & 15 \mathrm{~min} \\ 11 & \text { Fraction (IV) } & 2 \times 4 G y & 45 \mathrm{~min}\end{array}$

b

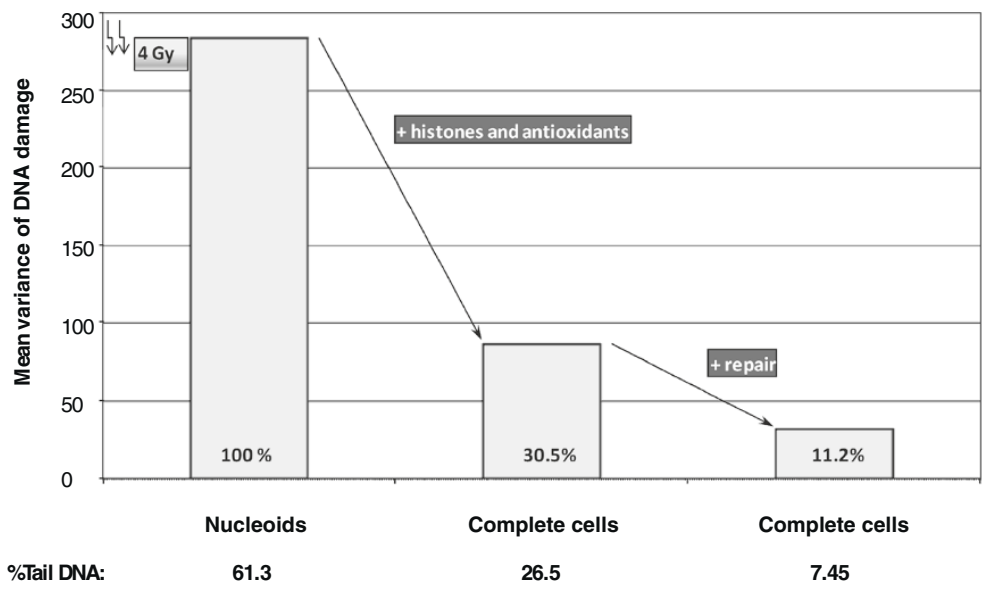

C

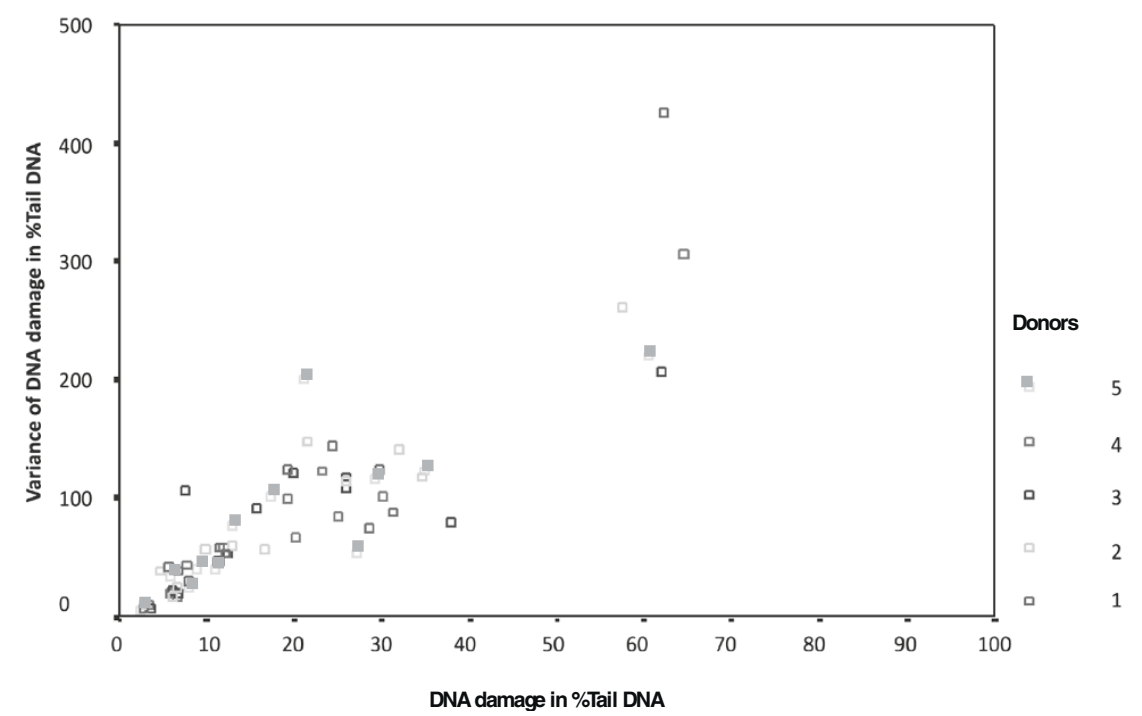

Figure 3 (See legend on next page.) 
(See figure on previous page.)

Figure 3 DNA damage and heterogeneity. a) Mean variance and DNA damage in \%Tail DNA measured after different experimental conditions (see Figure 1) were shown ${ }^{*}$ b) The reduction of heterogeneity by histones plus antioxidants and subsequent repair after 4 Gy was represented. Both conditions decreased heterogeneity of DNA damage to approximately one third of the initial level (fraction II i.e. pure DNA plus 4 Gy) ${ }^{*}$. c) The positive correlation (Pearson and Bravais'correlation, $r=+0.880 ; p<0.001$ ) between DNA damage in \%Tail DNA and variance of DNA damage was further substantiated by multiple linear regression $\left(R^{2}=0.771\right)$ indicating a $77.1 \%$ dependency of variance by changes of DNA damage. The relationship between both parameters was visualised by a scatter graph (12 samples with 5 independent experiments, $n=60$ ) ${ }^{* *}$.200 leukocytes/sample of each donor were measured for calculation of DNA damage in \%Tail DNA and variance. Mean variance was calculated from 5 donors.

double fractionated irradiation with subsequent repair. Therefore, this parameter might be used to further characterize radiation sensitivity as a factor which is independent of absolute response rate.

Our approach offers several practical implications with regard to optimization of radiosensitivity testing by comet assay. Dose response curves are generally compared by changes of mean \%Tail DNA or Tail moment. Statistical evaluations of comet assay data were usually performed with a parametric (t-test) or less powerful non-parametric tests (Wilcoxon-test, Mann-Whithney-U-test and others) [37]. Recently ANOVA was recommended as a statistical analysis strategy by the Pharmaceutical Industry Toxicology Special Interest Group [38]. If heterogeneity of radiation response is regarded as an additional valuable parameter for radiosensitivity, ANOVA has the advantage to integrate this information.

Especially in cell lines with same \%Tail DNA levels, different heterogeneity might influence biological behaviour and potentially explain occasional discrepancies between comet assay and response prediction assays such as colony forming unit $[39,40]$ or micronucleus assay [41], while most others found good correlations [42-47] or recommended considering multiple parameters [48]. As cell lines with homogeneous response biologically might differ from cell lines with heterogeneity due to radioresistant subgroups [18], heterogeneity might be a marker for less

Table 4 Correlation between \%Tail DNA and variance

\begin{tabular}{lcc}
\hline Factor & \multicolumn{2}{c}{ Changes of amount of } \\
\cline { 2 - 3 } & \%Tail DNA & Variance \\
\hline Single irradiation vs. no irradiation & $\uparrow$ & $\uparrow$ \\
Single irradiation and repair & $\downarrow$ & $\downarrow$ \\
Double irradiation vs. no irradiation & $\uparrow$ & $\uparrow$ \\
Double irradiation and repair & $\downarrow$ & $\downarrow$ \\
Double vs. single irradiation (+/- repair) & No change & $\uparrow$ \\
Loss of antioxidants and chromatin & $\uparrow \uparrow$ & $\uparrow \uparrow$ \\
Addition of antioxidants & $\downarrow$ & $\downarrow$ \\
\hline
\end{tabular}

Positive correlation of \%Tail DNA and variance according to measurements of Table 2 and 3 were indicated by arrows. The only measurements with no change in damage but increase in heterogeneity were comparisons of single vs. double fractionated irradiation. Therefore, this parameter could potentially work as a differentiator of radiation sensitivity.

Abbreviations: $\uparrow \uparrow=$ very strong increase, $\uparrow=$ increase, $\downarrow=$ decrease. predictable response due to a non-negligible amount of resistant cells. From this point of view, the biological relevance of heterogeneity is obvious and the here described method of modification and calculation might enhance response prediction.

Therefore, additional parameters such as variance of initial and residual damage and the implementation of a second radiation course could expand the available set of methods for improved prediction of radiation sensitivity by comet assay.

\section{Conclusions}

Heterogeneity of comet assay data measured by variance can be selectively modified by changes of chromatin structure, antioxidant concentration, repair and radiation dose. This finding facilitates optimization of experimental conditions by reducing scatter of comet assay data, potentially allowing improved discrimination of small differences and additional radiobiological characterization of cell lines by the amount of heterogeneity.

\section{Competing interests}

The authors declare that they have no competing interests.

\section{Authors' contributions}

CS has made substantial contributions to acquisition, analysis and interpretation of data. CL has made statistical evaluation and gave advice regarding statistical models and interpretation of data. JD has been involved in revising the manuscript for important intellectual content and has given final approval of the version to be published. ACM has made substantial contributions to conception, design and interpretation of data and manuscript. All authors read and approved the final manuscript.

\section{Author details}

'Department of General Psychiatry I, PZN-Wiesloch, Teaching Hospital of Ruprecht-Karls-University Heidelberg, Heidelberger Str. 1a, Wiesloch 69168, Germany. ${ }^{2}$ Institute of Biostatistics, Martin-Luther-University, Magdeburger Straße 8, Halle 06112, Germany. ${ }^{3}$ Department of Radiotherapy, University of Lübeck, Ratzeburger Allee 160, Lübeck 23538, Germany. ${ }^{4}$ Department of Radiooncology, Eberhard-Karls-University, Hoppe-Seyler-Strasse 3, Tübingen, Germany.

Received: 23 January 2012 Accepted: 11 April 2012

Published: 20 April 2012

\section{References}

1. Kuechler A, Neubauer S, Grabenbauer GG, Claussen U, Liehr T, Sauer R, Wendt TG: Is 24-color FISH detection of in-vitro radiation-induced chromosomal aberrations suited to determine individual intrinsic radiosensitivity? StrahlentherOnkol 2002, 178:209-215.

2. Rosenberger A, Rossler U, Hornhardt S, Sauter W, Bickeboller H, Wichmann HE, Gomolka M: Validation of a fully automated COMET assay: 1.75 
million single cells measured over a 5 year period. DNA Repair (Amst) 2011, 10:322-337.

3. Al-Assar O, Muschel RJ, Mantoni TS, McKenna WG, Brunner TB: Radiation response of cancer stem-like cells from established human cell lines after sorting for surface markers. Int J Radiat Oncol Biol Phys 2009, 75:1216-1225.

4. Louagie H, Van Eijkeren M, Philippe J, Thierens H, de Ridder L: Changes in peripheral blood lymphocyte subsets in patients undergoing radiotherapy. Int J Radiat Biol 1999, 75:767-771.

5. Baumann M, Krause M, Thames H, Trott K, Zips D: Cancer stem cells and radiotherapy. Int J Radiat Biol 2009, 85:391-402.

6. Betti C, Davini T, Giannessi L, Loprieno N, Barale R: Comparative studies by comet test and SCE analysis in human lymphocytes from 200 healthy subjects. Mutat Res 1995, 343:201-207.

7. Frenzilli G, Betti C, Davini T, Desideri M, Fornai E, Giannessi L, Maggiorelli F, Paoletti P, Barale R: Evaluation of DNA damage in leukocytes of ex-smokers by single cell gel electrophoresis. Mutat Res 1997, 375:117-123.

8. Östling O, Johanson KJ: Microelectrophoretic study of radiation-induced DNA damages in individual mammalian cells. BiochemBiophysResCommun 1984, 123:291-298.

9. Anderson D, Plewa MJ: The International Comet Assay Workshop. Mutagenesis 1998, 13:67-73.

10. Rojas E, Lopez MC, Valverde M: Single cell gel electrophoresis assay: methodology and applications. JChromatogrB BiomedSciApp/1999, 722:225-254.

11. Singh NP, Stephens RE, Schneider EL: Modifications of alkaline microgel electrophoresis for sensitive detection of DNA damage. IntJRadiatBiol 1994, 66:23-28.

12. Singh NP, McCoy MT, Tice RR, Schneider EL: A simple technique for quantitation of low levels of DNA damage in individual cells. ExpCell Res 1988, 175:184-191

13. Olive PL, Banath JP: The comet assay: a method to measure DNA damage in individual cells. Nat Protoc 2006, 1:23-29.

14. Ljungman M: The influence of chromatin structure on the frequency of radiation-induced DNA strand breaks: a study using nuclear and nucleoid monolayers. Radiat Res 1991, 126:58-64.

15. Ljungman M, Nyberg S, Nygren J, Eriksson M, Ahnstrom G: DNA-bound proteins contribute much more than soluble intracellular compounds to the intrinsic protection against radiation-induced DNA strand breaks in human cells. Radiat Res 1991, 127:171-176.

16. Olive PL, Banath JP, Durand RE: Heterogeneity in radiation-induced DNA damage and repair in tumor and normal cells measured using the "comet" assay. Radiat Res 1990, 122:86-94.

17. Visvardis E, Haveles KS, Pataryas TA, Margaritis LH, Sophianopoulou V, Sideris EG: Diversity of peripheral blood mononuclear cells as revealed by a novel multiple microgel "comet assay". Environ Mol Mutagen 2000, 36:3239.

18. Olive PL, Banath JP, Durand RE: Detection of subpopulations resistant to DNA-damaging agents in spheroids and murine tumours. Mutat Res 1997, 375:157-165

19. Hu Q, Kavanagh MC, Newcombe D, Hill RP: Detection of hypoxic fractions in murine tumors by comet assay: comparison with other techniques. Radiat Res 1995, 144:266-275.

20. Olive PL, Vikse CM, Durand RE: Hypoxic fractions measured in murine tumors and normal tissues using the comet assay. Int J Radiat Oncol Biol Phys 1994, 29:487-491.

21. Collins A, Dusinska M, Franklin M, Somorovska M, Petrovska H, Duthie S, Fillion L, Panayiotidis M, Raslova K, Vaughan N: Comet assay in human biomonitoring studies: reliability, validation, and applications. EnvironMolMutagen 1997, 30:139-146.

22. Fairbairn DW, Olive PL, O'Neill KL: The comet assay: a comprehensive review. MutatRes 1995, 339:37-59.

23. Mueller AC, Beyer C, Pigorsch SU, Haensgen G, Sieker FP, Dunst J: Radioprotective effects of amifostine in-vivo and in-vitro. Int J Radiat Oncol Biol Phys 2003, 57:S160-S161.

24. Muller AC, Pigorsch S, Beyer C, Lautenschlager C, Dunst J: Radioprotective effects of amifostine in vitro and in vivo measured with the comet assay. StrahlentherOnkol 2004, 180:517-525.

25. Olive PL: Impact of the comet assay in radiobiology. Mutat Res 2009, 681:13-23.
26. Moller $P$, Knudsen LE, Loft $S$, Wallin $H$ : The comet assay as a rapid test in biomonitoring occupational exposure to DNA-damaging agents and effect of confounding factors. Cancer Epidemiol Biomarkers Prev 2000, 9:1005-1015.

27. Toyoizumi T, Ohta R, Nakagawa Y, Tazura Y, Kuwagata M, Noguchi S, Yamakage K: Use of the in vivo skin comet assay to evaluate the DNAdamaging potential of chemicals applied to the skin. Mutat Res 2011, 726:175-180.

28. Lankinen MH, Vilpo LM, Vilpo JA: UV- and gamma-irradiation-induced DNA single-strand breaks and their repair in human blood granulocytes and lymphocytes. Mutat Res 1996, 352:31-38.

29. Banath JP, Wallace SS, Thompson J, Olive PL: Radiation-induced DNA base damage detected in individual aerobic and hypoxic cells with endonuclease III and formamidopyrimidine-glycosylase. RadiatRes 1999, 151:550-558.

30. Falbo KB, Alabert C, Katou Y, Wu S, Han J, Wehr T, Xiao J, He X, Zhang Z, Shi $Y$, Shirahige K, Pasero $P$, Shen $X$ : Involvement of a chromatin remodeling complex in damage tolerance during DNA replication. Nat Struct Mol Biol 2009, 16:1167-1172.

31. Banath JP, Banuelos CA, Klokov D, MacPhail SM, Lansdorp PM, Olive PL: Explanation for excessive DNA single-strand breaks and endogenous repair foci in pluripotent mouse embryonic stem cells. Exp Cell Res 2009, 315:1505-1520.

32. Barone F, Belli M, Pazzaglia S, Sapora O, Tabocchini MA: Radiation damage and chromatin structure. Ann Ist Super Sanita 1989, 25:59-67.

33. Mosesso P, Palitti F, Pepe G, Pinero J, Bellacima R, Ahnstrom G, Natarajan AT: Relationship between chromatin structure, DNA damage and repair following X-irradiation of human lymphocytes. Mutat Res 2010, 701:86-91.

34. Zhang L, Jones K, Gong F: The molecular basis of chromatin dynamics during nucleotide excision repair. Biochem Cell Biol 2009, 87:265-272.

35. Tawar U, Bansal S, Shrimal S, Singh M, Tandon V: Nuclear condensation and free radical scavenging: a dual mechanism of bisbenzimidazoles to modulate radiation damage to DNA. Mol Cell Biochem 2007, 305:221-233.

36. Tiwari P, Kumar A, Balakrishnan S, Kushwaha HS, Mishra KP: Radiationinduced micronucleus formation and DNA damage in human lymphocytes and their prevention by antioxidant thiols. Mutat Res 2009, 676:62-68.

37. Lovell DP, Omori T: Statistical issues in the use of the comet assay. Mutagenesis 2008, 23:171-182.

38. Bright J, Aylott M, Bate S, Geys H, Jarvis P: Saul J. Vonk R: Recommendations on the statistical analysis of the Comet assay. Pharm Stat; 2011.

39. Oppitz U, Schulte S, Stopper H, Baier K, Muller M, Wulf J, Schakowski R, Flentje $\mathrm{M}:$ In vitro radiosensitivity measured in lymphocytes and fibroblasts by colony formation and comet assay: comparison with clinical acute reactions to radiotherapy in breast cancer patients. Int J Radiat Biol 2002, 78:611-616.

40. Dunne AL, Price ME, Mothersill C, McKeown SR, Robson T, Hirst DG: Relationship between clonogenic radiosensitivity, radiation-induced apoptosis and DNA damage/repair in human colon cancer cells. Br J Cancer 2003, 89:2277-2283.

41. He JL, Chen WL, Jin LF, Jin HY: Comparative evaluation of the in vitro micronucleus test and the comet assay for the detection of genotoxic effects of X-ray radiation. Mutat Res 2000, 469:223-231.

42. Mughal A, Vikram A, Ramarao P, Jena GB: Micronucleus and comet assay in the peripheral blood of juvenile rat: establishment of assay feasibility, time of sampling and the induction of DNA damage. Mutat Res 2010, 700:86-94.

43. Jiang W, Lu Y, Chen Z, Chen S, Zhang M, Jin L, Lou J, He J: Studying the genotoxicity of vincristine on human lymphocytes using comet assay, micronucleus assay and TCR gene mutation test in vitro. Toxicology 2008, 252:113-117.

44. Rzeszowska-Wolny J, Palyvoda O, Polanska J, Wygoda A, Hancock R: Relationships between acute reactions to radiotherapy in head and neck cancer patients and parameters of radiation-induced DNA damage and repair in their lymphocytes. Int J Radiat Biol 2008, 84:635-642.

45. Kim IY, Hyun CK: Comparative evaluation of the alkaline comet assay with the micronucleus test for genotoxicity monitoring using aquatic organisms. Ecotoxicol Environ Saf 2006, 64:288-297.

46. He JL, Chen WL, Jin LF, Jin HY, Eastham AM, Marples B, Kiltie AE, Orton CJ, West CM: Comparative evaluation of the in vitro micronucleus test and the comet assay for the detection of genotoxic effects of X-ray radiation 
Fibroblast radiosensitivity measured using the comet DNA-damage assay correlates with clonogenic survival parameters. Mutat Res 2000, 469:223-231.

47. Streffer C: Genetic predisposition and radiation sensitivity of normal tissue. Strahlenther Onkol 1997, 173:462-468.

48. Abend M, Kehe K, Kehe K, Riedel M, Van Beuningen D: Correlation of micronucleus and apoptosis assays with reproductive cell death can be improved by considering other modes of death. Int J Radiat Biol 2000, 76:249-259.

doi:10.1186/1748-717X-7-61

Cite this article as: Seidel et al:: Factors influencing heterogeneity of radiation-induced DNA-damage measured by the alkaline comet assay. Radiation Oncology 2012 7:61.

\section{Submit your next manuscript to BioMed Central and take full advantage of:}

- Convenient online submission

- Thorough peer review

- No space constraints or color figure charges

- Immediate publication on acceptance

- Inclusion in PubMed, CAS, Scopus and Google Scholar

- Research which is freely available for redistribution 